\title{
EXPERIENTIAL MARKETING AND EXPERIENTAL VALUE, HOW DOES IT IMPACT ON CONSUMER REPURCHASE INTENTIONS
}

\author{
Beatrice Tan Yanto ${ }^{1}$ \\ Tuty Lindawati ${ }^{2}$ \\ Dominicus Wahyu Pradana ${ }^{3}$ \\ Business Faculty, Management Department, \\ Widya Mandala Catholic University Surabaya- Indonesia \\ wahyupradana@ukwms.ac.id
}

\section{A R T I C L E I N F O}

Article history:

Received : 4 April 2020

Revised : 20 April 2020

Accepted : 1 May 2020

JEL Classification:

Key words:

Experiential Marketing, Experiential Value, Repurchase Intenion.

DOI:

https://doi.org/10.33508/rima.v3i1.2746

\begin{abstract}
A B S T R A C T
Today's competition is very intens, with many restaurants, cafes and food court popping up so that competition arises from the side of sellers and consumers. Today's consumers are more likely to get bored so quickly that they will use all existing facilities such as information technology to get information about what they want to know. Marketers must have a positive strategy in experiential marketing to create a good experience for consumers.

This study aims to determine the effect of experiential marketing on repurchase intention through experiential value for consumers of Pasa Rame Restaurant in Surabaya. Respondent samples used were 200 respondents who are the consumers of Pasa Rame Restaurant in Surabaya. Sampling of respondents using non probability sampling by purposive sampling. The data collection tool used is a questionnaire. The data analysis technique used is the Structural Equation Modelling using the Lisrel program.The results of this study state that experiential marketing has a positive and significant effect on experiential value, experiential marketing has a positive and significant effect on repurchase intention, experiential value has a positive and significant effect on repurchase intention and experiential marketing has a positive and significant effect on repurchase intention through experiential value for consumers of Pasa Rame Restaurant in Surabaya
\end{abstract}

\section{INTRODUCTION}

The increasing number of infrastructure built, such as roads, can facilitate access from one place to another. The better the infrastructure, the more entrepreneurs are making restaurants, especially in Surabaya. The need for food and drinks is a basic human need, but for now, it is not just eating when in a restaurant but for hangouts, meeting places, and even for taking selfies. With the emergence of many restaurants, it allows many choices for consumers. Besides that, with the development of increasingly sophisticated technology, it makes it easier for promotional media so that this makes it even easier for consumers to choose a restaurant. The following is data on the number of restaurants or restaurants in Surabaya:

Table 1

Number of Restaurants in Surabaya

\begin{tabular}{|c|c|}
\hline Year & Amount (Unit) \\
\hline 2013 & 391 \\
\hline 2014 & 383 \\
\hline
\end{tabular}




\begin{tabular}{|c|c|}
\hline 2015 & 713 \\
\hline 2016 & 790 \\
\hline
\end{tabular}

Source: http://jatim.bps.go.id

Based on Table 1, the number of restaurants/restaurants from 2013 to 2014 has decreased by $2.05 \%$. In 2014-2015, the number of restaurants/restaurants in Surabaya had increased significantly, namely by $86.16 \%$, and in 2016 also increased although not so significant, namely $10.8 \%$. This shows that many restaurants started opening in 2015. The growth rate shows an increase, but the change in restaurant performance is stagnant, which means no increase. According to the Food and Beverages industry records in 2017, some experienced closures or went out of business, but this condition was covered up because there were new openings (Surya.co.id, 2018). The problem that occurs is due to the requirements of intense competition from the marketer's side and from the consumer, namely consumers who are easily bored. More and more new restaurants are opening with massive promotions. Marketers have to think about solutions to increase sales and make consumers want to return to the restaurant. Restaurants must be able to keep customers from coming back to continue to maintain their business.

One solution that marketers can do is to provide positive experience benefits to consumers so that consumers have the intention to return to the restaurant. Marketers can use the science of marketing management called experiential marketing, which means creating a marketing experience (experiential marketing) so that consumers have the intention to return. Experiential marketing and experiential value are concepts that are positively related (Schmitt, 1999). Analysis of experiential value impacts purchases (Wong and May in Astari and Pramudana, 2016). Astari and Pramudana (2016) state that experiential value has a positive and significant effect in mediating experiential marketing's impact on repurchase intention.

Many researchers have implemented experiential marketing to create an intention to return to consumption by involving experiential value (Nigam, 2012; Astari and Pramudana, 2016). Sense experience (sense marketing) has an impact on satisfaction and repurchase intention. In other words, restaurants provide consumers with an extraordinary taste experience (Razi and Lajevardi, 2016).

Schmitt (1999) divides experiential marketing into five dimensions, namely sense (a sensory experience), feel (affective experience), think (creative cognitive experience), act (physical expertise, behavior, and lifestyle), and relate (socioidentity knowledge of relationships). With reference communities or cultures). According to Andreani (2007), experiential marketing is a marketing concept that not only provides information and opportunities for customers to gain experience or benefits but also evokes emotions and feelings that are impacted on marketing, especially sales.

The experiential value view is based on existing interactions, including direct use or appreciation of consumers' products and services (Rosanti et al., 2014). From a managerial perspective, the value of experience is an essential consideration in the economy of recent experiences (Varshneya et al., 2017). According to Nigam (2012), and extrinsic and intrinsic value from experiential value includes four dimensions: consumer return on investment, service excellence, aesthetic, and playfulness.

One indicator of a company's success is determined by the consumer's continued repurchase interest (Astari and Pramudana, 2016). The excellent 
experience that customers receive from service is another thing that can increase repurchase intentions (Chang et al., 2018). Consumers' decisions about buying back services from companies depend on their past experiences, and consumers will see the current situation and conditions (Hellier et al., 2003).

Nowadays, consumers come to restaurants not just to eat, but can be used for other activities so that restaurants must provide experiences for consumers. Moreover, now a restaurant or cafe is a place to relax so that the mind and spirit can calm down after a tiring day of activities. Pasa Rame is a new restaurant with a food court theme and is located in a mall. Pasa Rame itself is a restaurant owned by the East Java Boga Group. Besides having a creative piece, namely the food court theme, Pasa Rame also uses local music for its cuisine, which means that food, from appetizers to desserts and drinks, is authentic Indonesian local food. The slogan used by the Rame is "Foodventure Yuk," which means Pasa Rame wants to give the impression of a food adventure because the food sold is different from different layouts. By using a creative theme, Pasa Rame tries to provide a new atmosphere so that consumers don't get bored because more than ten foods are sold with a food court concept. The food dishes offered are fried rice, gejrot tofu, crab noodles, and many others. There are modern herbal medicine, coffee pull, young coconut, and many other choices as for drinks. The dessert menu offered is Ice Doger, Pontianak Ice, Cendol Ice, Moonlight, and there are still different dessert menus. Pasa Rame is visited by many students, students, and workers. Besides being used for young people, Pasa Rame is also a culinary destination for families to eat and spend time with family to enjoy holidays. Pasa Rame is located in two Surabaya malls, namely Pakuwon Mall and Tunjungan Plaza 6.

This research focuses on the experiential marketing approach applied by Pasa Rame based on managerial and theoretical aspects. It can create repurchase intention through experiential value among Pasa Rame consumers in Surabaya, so that the title of this research is The Effect of Experiential Marketing on Repurchase Intention through Experiential Value to Consumers. Pasa Rame in Surabaya.

\section{THEORICAL BASIS}

Experiential Marketing

Schmitt argues that experiential marketing is the ability of a product to offer emotional experiences to touch consumers' hearts and feelings (Schmitt, 1999: 33-34; in Saraswati, et al., 2013). Experiential marketing is a marketing concept that aims to form loyal customers by touching customer emotions by creating positive experiences and providing a positive feeling for their services and products (Kertajaya., 2010: 23; in Saraswati, et al., 2013). Experiential marketing is broadly defined as any form of customer-focused marketing activity that creates a connection to the customer. Based on this view, experiences can be generated by-products, packaging, communications, in-store interactions, sales relationships, events, and the like (Schmitt, 2010). According to Schmitt (1999), experiential marketing has five dimensions. Namely, sense, feel, think, act, and relate.

\section{Experiental Value}

Holbrook (1994, in Mathwick, Malhotra, and Rigdon, 2001) states that "experiential value has been defined as perceptions and interactions involving either direct usage or distanced appreciation of goods and services. These interactions provide the basis for the relativistic preferences held by the individuals involved ".

Mathwick et al. (2001, in Nigam, 2012) develop a typology of experiential value and reveal that experiential value offers extrinsic and intrinsic benefits that can have a long-term impact on 
consumers' minds. The extrinsic value of experiential value includes two dimensions: consumer return on investment and service excellence. Meanwhile, the intrinsic value of experiential value has aesthetics and playfulness.

\section{$\underline{\text { Repurchase Intention }}$}

The beliefs and attitudes formed at the post-purchase stage will directly influence future purchase intentions, oral communication, and complaint behavior. These beliefs and attitudes can be in postdecision regret and consumer satisfaction or dissatisfaction (Engel et al., 1995: 209210). According to Zeithaml, Berry, and Parasuraman (1996), repurchase intention occurs when consumers make repeated purchases of the same product or service. Mowen and Minor (2005: 110) also state that consumers make repeat purchases not based on unique feelings about a product but only make repeated purchases.

Hellier et al. (2003) stated that "repurchase intention. The individual's judgment about buying a designated service again from the same company takes into account his or her current situation and likely circumstances.

According to Jones et al. (2000, in Jones and Taylor, 2007), repurchase intention is "customer's aim to maintain a relationship with a particular service provider and make his or her next purchase in the category from this service provider." According to Schiffman and Kanuk (2008: 506), repeat purchases usually indicate that the product is according to consumer desires, and consumers are willing to use it again and in larger quantities.

According to Kolter and Armstrong (2014: 178), repurchase intention is a post-purchase consumer action. Post-purchase consumer action is influenced by consumer satisfaction and dissatisfaction so that when consumers feel satisfied with the product or service provided, the consumer will make a repeat purchase. However, if consumers are not happy with the products or services provided, they will not buy them anymore.

According to Oliver (2015: 427), repurchase intention is a result of the influence of consumer attitudes after using the product or service offered, and this will be used by product or service providers to improve their performance continuously.

\section{Research Hypothesis}

H1: Experiential marketing has a positive effect on experiential value.

H2: Experiential marketing has a positive effect on repurchase intention.

H3: Experiential value has a positive effect on repurchase intention.

H4: Experiential marketing has a positive effect on repurchase intention through experiential value.

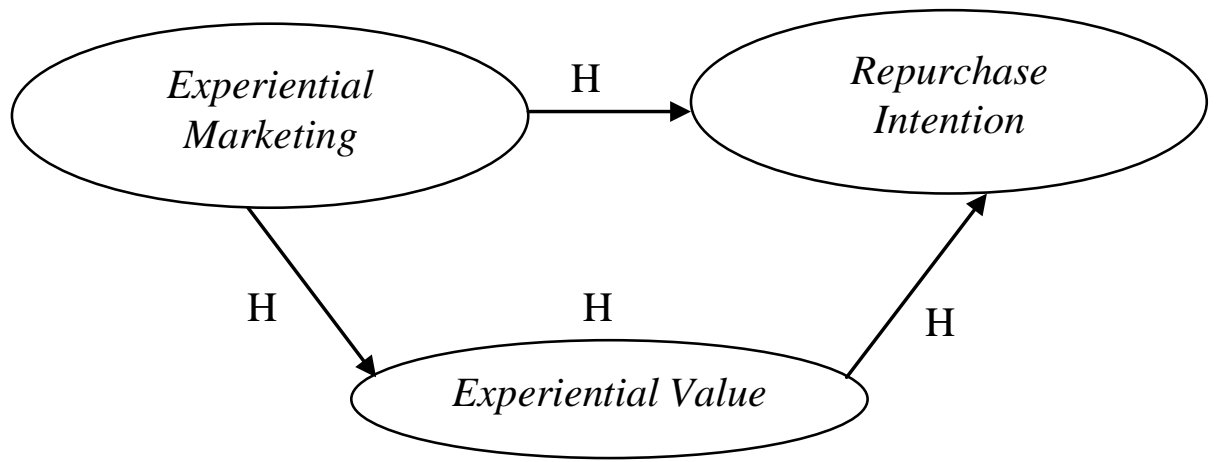

Figure 1 Research Model

METHOD
This study uses a type of causality research because it aims to examine the 
causal relationship between two or more variables. The objects used in this study are consumers of Pasa Rame Restaurant in Surabaya who have visited the restaurant in the last six months and are over 17 years old. The sample is determined by the nonprobability sampling technique using purposive sampling. The number of pieces used was 200 respondents who were taken from the total population by selecting the sample based on the opinion of Hair et al., namely the number of indicators as much as 29 times 5. This study consisted of quantitative data, namely, gender, age, and occupation. The analysis technique used to perform data processing in this study is structural equation modeling (SEM) using the Lisrel program.

\section{RESULT}

\section{Descriptive Findings}

Based on the research results, the number of respondents based on gender is $49 \%$ male and $51 \%$ female. More respondents aged 17-27 years, namely
$79 \%$, while respondents aged $>27-38$ is $13.5 \%$ and respondents aged $>38-49$ are $5.5 \%$. Respondents aged $>49-60$ are the least respondent's age, which is only $2 \%$. In line with most respondents' age is 17-27 years old, this is following the results that most of the respondents are students, with a total of $73 \%$. Meanwhile, respondents for civil servants, private employees, selfemployed workers, and others are $1 \%$, $13 \%, 8.5 \%$, and $4.5 \%$.

\section{Measurement Model Evaluation}

Here is a table Overall Model Evaluation of the research that has been done. Table 2 shows that of the eight measurements used, not all of them show a good fit, but only GFI and AGFI do not offer good fit results. However, this model can still be used in research. Validity and reliability testing has been carried out, and it shows that each indicator of each variable is valid, which means that all hands can be used. And for the reliability test, the result is each variable is reliable.

Table 2 Overall Model Evaluation

\begin{tabular}{|c|c|c|c|}
\hline Goodness of Fit Index & Cut off Value & Result & Information \\
\hline GFI & $\geq 0,9$ & 0,74 & Un Fit \\
\hline AGFI & $\geq 0,9$ & 0,70 & Un Fit \\
\hline NFI & $\geq 0,9$ & 0,95 & Good Fit \\
\hline IFI & $\geq 0,9$ & 0,97 & Good Fit \\
\hline CFI & $\geq 0,9$ & 0,97 & Good Fit \\
\hline RFI & $\geq 0,9$ & 0,94 & Good Fit \\
\hline RMSEA & $<0,08$ & 0,071 & Good Fit \\
\hline Normed Chi Square & $1 \leq X^{2} / \mathrm{df} \leq 5$ & 1,99 & Good Fit \\
\hline
\end{tabular}

Table 3 Hypotesis Test Result

\begin{tabular}{|c|c|c|c|c|c|}
\hline Hipotesis & $\begin{array}{c}\text { Hubungan } \\
\text { Variabel }\end{array}$ & $\begin{array}{c}\text { Loading } \\
\text { Factor }\end{array}$ & t-Value & Cut-off & Keterangan \\
\hline $\mathrm{H}_{1}$ & EM -> EV & 1,61 & 7,53 & 1,96 & Signifikan \\
\hline $\mathrm{H}_{2}$ & EM -> RI & 1,86 & 2,10 & 1,96 & Signifikan \\
\hline $\mathrm{H}_{3}$ & EV -> RI & 0,60 & 2,43 & 1,96 & Signifikan \\
\hline $\mathrm{H}_{4}$ & $\mathrm{EM} \mathrm{->} \mathrm{EV->} \mathrm{RI}$ & 0,97 & 2,40 & 1,96 & Signifikan \\
\hline
\end{tabular}

Hypothesis 1 shows significant results and following the research that has been conducted by Astari and Pramudana (2016), who prove that experiential marketing has a substantial and positive influence on experiential value. The feel dimension, which is part of experiential marketing, can create a consumer return on investment (CROI), which is part of experiential value. Other supporting 
research results are the research results by Kusuma (2013), which proves that experiential marketing has a significant and positive effect on experiential value so that the higher the experiential marketing, the higher the consumer's experiential value. Nigam (2012) also states that experiential marketing has a significant and positive effect on experiential value. This research also support theory from Schmitt (1999) that state experiental marketing and experiental value was an inseparable concept and have a positive relationship

Hypothesis 2 shows significant results and, following the research that has been conducted by Astari and Pramudana (2016), states that experiential marketing has a positive and significant effect on repurchase intention. Other supporting research results, namely the results of research conducted by Razi and Lajevardi (2016), found that experiential marketing sense impacts repurchase intention. In other words, restaurants provide consumers with an extraordinary taste experience.

Hypothesis 3 shows significant results and, following the research that has been conducted by Astari and Pramudana (2016), stated that experiential value has a significant positive effect on repurchase intention. This means that the higher the application of experiential value is carried out, the more positive the repurchase intention is created by consumers. Other supporting research results are research conducted by Chang et al. (2018), which states that experiential value positively affects repurchase intention. According to Chang et al. (2018), by maintaining quality and use value, increasing consumer confidence will retain consumers. Kusuma (2013) stated that experiential value has a positive and significant effect on his research.

Hypothesis 4 shows significant results and follows the research conducted by Astari and Pramudana(2016), which states that feel which is part of experiential marketing has created a consumer return on investment (CROI), which is part of experiential value. Furthermore, this can affect consumer repurchase interest, indicated by the desire to invite relatives and closest people to visit again. Other supporting research results are the research results conducted by Kusuma (2013), which states that experiential marketing has a significant and positive effect on repurchase intention through experiential value.

\section{CONCLUSIONS}

From the results of hypothesis testing and discussion that has been described in the previous chapter, it can be concluded that experiential marketing has a positive and significant effect with a substantial direct effect on Experiential Value. Experiential Marketing has a positive and significant impact, but the immediate effect is weak on Repurchase Intention. Experiential Value has a positive and significant impact, with a substantial direct effect on Repurchase. Experiential Marketing has a positive and significant impact on Repurchase Intention through Experiential Value. The influence of the intervening variable (indirect effect) of Experiential Value is strong.

\section{$\underline{\text { Suggestions }}$}

For further researchers, it is better if in conducting research using research objects permitted by the manager to distribute questionnaires directly at the place of the research object so that the results obtained become more accurate and concrete.

This research is expected to provide good views or ideas on the Pasa Rame Restaurant. The following are suggestions put forward at Pasa Rame Restaurant:

- Experiential marketing that has been carried out by Pasa Rame Restaurant is useful, such as attractive design, diverse food, and is located in a strategic area. 
However, Pasa Rame Restaurant is still only in 2 places, so it is better if the manager has more branches to be easily accessible to consumers.

- The experimental value that consumers get is good. Still, the manager should offer discounts, attractive promos so that consumers want to make repeat purchases because the prices shown by Pasa Rame Restaurant are quite expensive with not many portions. So that by giving attractive discounts, consumers will be more frequent to make purchases again.

- Pasa Rame Restaurant can also take advantage of the convenience of payment through applications currently booming such as Go-pay and Ovo, in filling up member payment cards owned by consumers so that consumers don't have to queue to top up their balances when eating at Pasa Rame Restaurant.

- Pasa Rame Restaurant can work with the Surabaya city government in developing its culinary business because currently, the government is planning to create a creative economy, especially in the culinary field. Pasa Rame Restaurant can work with the government, for example, by using partners from MSMEs facilitated by the government and making Pasa Rame Restaurant a place to make work visits and culinary tours from government agencies from outside the Surabaya area.

\section{REFERENCE}

Andreani, F. (2007). Experiential Marketing (Sebuah Pendekatan Pemasaran). Jurnal Manajemen Pemasaran , 1-8.

Araci, U., Bulut, Z., \& Kocak, N. (2017). The Relation Among
Experiential Marketing,

Customer Satisfaction, and Behavioral Intention: A Study on Food and Beverage Businesses. 23rd International Scientific Conference on Economic and Social Development , 361-371.

Astari, W. F., \& Pramudana, K. A. (2016). Peran Experiential Value dalam Memediasi Pengaruh Experiential Marketing terhadap Repurchase Intention. Jurnal Manajemen, Strategi Bisnis dan Kewirausahaan, (10)1, 16-30.

Badan Pusat Statistik Provinsi Jawa Timur. (2017). Jumlah Restoran/Rumah Makan Menurut Kabupaten/Kota di Provinsi Jawa Timur, 2013 - 2016. Dipetik Juni 1，2018， dari https://jatim.bps.go.id/dynami ctable/2017/10/17/137/jumlah -restoran-rumah-makanmenurut-kabupaten-kota-diprovinsi-jawa-timur-2013--2016.html

Chang, W.-J., Liao, S.-H., Chung, Y.-C., \& Chen, H.-P. (2018). Service Quality, Experiential Value and Repurchase Intention for Medical Cosmetology Clinic: Moderating Effect of Generation. Total Quality Management \& Business Excellence , 1-21.

Durianto, D., Sugiarto, \& Tony, S. (2001). Strategi Menaklukkan Pasar melalui Riset Ekuitas dan Perilaku Merek. Jakarta: Gramedia Pustaka Utama.

Engel, J., Blackwell, R., \& Miniard, P. (1995). Perilaku Konsumen [Terjemahan] (edisi ke-6). Jakarta: Binarupa Aksara.

Hair, J., Black, W., Babin, B., \& Anderson, R. (2013). Multivariate Data Analysis: Pearson New International Edition . Upper Saddle River: Pearson Education Limited. 
Hellier, P. K., Geursen, G. M., Carr, R. A., \& Rickard, J. A. (2003). Customer Repurchase Intention: A General Structural Equation Model. European Journal of Marketing, (37)11/12 , 17621800.

Jones, T., \& Taylor, S. (2007). The Conceptual Domain of Service Loyalty: How many Dimensions? Journal of Services Marketing, (21)1 , 36-51.

Kotler, P., \& Armstrong, G. (2014). Principles of Marketing. Edinburg: Pearson Education.

Kuncoro, M. (2013). Metode Riset Untuk Bisnis \& Ekonomi (edisi ke-4). Jakarta: Erlangga.

Kusuma, A. (2013). Pengaruh Experiential Marketing terhadap Repurchase Intention melalui Experiential Value pada Maskapai Penerbangan Garuda Indonesia di Surabaya. Kajian Ilmiah Mahasiswa Manajemen (2)3, 16.

Lestari, S. H. (2018). Pertumbuhan Kinerja Restoran dan Kafe di Surabaya Stagnan, Pengusaha Diminta Lakukan ini. Dipetik Juni 2018, 1, dari Surya.co.id: http://surabaya.tribunnews.co $\mathrm{m} / 2018 / 01 / 19 /$ pertumbuhankinerja-restoran-dan-kafe-disurabaya-stagnan-pengusahadiminta-lakukan-ini?page $=$ all

Mathwick, C., Malhotra, N., \& Rigdon, E. (2001). Experiential Value: Conceptualization,

Measurement and Application in the Catalog and Internet Shopping Environment. Journal of Retailing, (77) , 39-56.

Mowen, J., \& Minor, M. (2005). Perilaku Konsumen Jilid 2 (edisi ke-5). Jakarta: Erlangga.

Nigam, A. (2012). Modeling Relationship Between Experiential Marketing, Experiential Value and Purchase Intentions in Organized Quick Service Chain
Restaurants Shoppers Using Structural Equation Modeling Approach. International Journal of Computer Science \& Management Studies, (12) , 7079.

Oliver, R. (2015). Satisfaction : A Behavioral Perspective on the Consumer (second edition). New York: Routledge.

Razi, F. F., \& Lajevardi, M. (2016). Sense Marketing,

Experiential Marketing, Customer Satisfaction, and Repurchase Intention. Journal of Marketing and Consumer Research, (21) , 67-73.

Rosanti, N., Kumadji, S., \& Yulianto, E. (2014). Pengaruh Experiential Marketing dan Experiential Value Terhadap Customer Satisfaction: Survei pada Mahasiswa FIA Bisnis 2013/2014 Pengguna Android Samsung. Jurnal Administrasi Bisnis, (16)1 , 1-7.

Rusli, M. (2014). Pengelolaan Statistik yang Menyenangkan. Yogyakarta: Graha Ilmu.

Saraswati, R., Arifin, Z., \& Yulianto, E. (2013). Pengaruh Experiential Marketing terhadap Loyalitas (Studi Pada Pelanggan Taman Indie Resto Malang). Jurnal Administrasi Bisnis , 1-9.

Schiffman, L., \& Kanuk, L. (2008). Perilaku Konsumen [Terjemahan] (edisi ke-7). Jakarta: Indeks.

Schmitt, B. (2010). Experience Marketing: Concepts, Frameworks and Consumer Insights. Foundations and Trend in Marketing, 5(2) , 55-112.

Schmitt, B. (1999). Experiential Marketing. Journal of Marketing Management, (15)1-3 , 53-67.

Silalahi, U. (2009). Metode Penelitian Sosial. Bandung: Refika Aditama. 
Sugiyono. (2011). Metode Penelitian Kuantitatif Kualitatif dan R\& D. Bandung: Alfabeta.

Varshneya, G., Das, G., \& Khare, A. (2017). Experiential Value: A Review and Future Research Directions. Marketing Inteligence \& Planning, (35) , 1-38.

Yamin, S. (2014). Rahasia Olah Data Lisrel. Jakarta: Mitra Wacana Media.
Yamin, S., \& Kurniawan, H. (2009). Structural Equation Modeling Belajar Lebih Mudah Teknik Analisis Data Kuesioner dengan Lisrel-PLS. Jakarta: Penerbit Salemba Infotek.

Zeithaml, V., Berry, L., \& Parasuraman, A. (1996). The Behavioral Consequences of Service Quality. Journal of Marketing, (60) , 31-46. 